\title{
Evaluating the Impact of Covid-19 Pandemic on Nutritional Habits and Supplementary Food Use in Dietetic Students
}

\section{Ayse Demet Karaman ${ }^{1 *}$, Beyza Hilal Ermis ${ }^{2}$, Ferit Cobanoglu ${ }^{3}$ and Didem Peren Aykas ${ }^{4}$}

${ }^{1}$ Department of Dairy Technology, Faculty of Agriculture, Aydın Adnan Menderes University, Aydın, Turkey

${ }^{2}$ Department of Nutrition and Dietetics, Faculty of Health Sciences, Aydin Adnan

Menderes University, Aydın, Turkey

${ }^{3}$ Department of Agricultural Economy, Faculty of Agriculture, Aydin Adnan

Menderes University, Aydın, Turkey

${ }^{4}$ Department of Food Engineering, Faculty of Engineering, Aydin Adnan Menderes

University, Aydın, Turkey

*Corresponding Author: Ayse Demet Karaman, Department of Dairy Technology,

Faculty of Agriculture, Aydın Adnan Menderes University, Aydın, Turkey.
Received: November 17, 2021

Published: November 25, 2021

(C) All rights are reserved by Ayse Demet

Karaman., et al.

\begin{abstract}
Nutrition and its role in coronavirus disease have gained significant attention, but the dietetic students' nutritional behaviors are not well-known. Therefore, this study investigates the changes in nutritional habits and the usage of food supplements during the Covid-19 pandemic in nutrition and dietetics students. A total of 211 students from the $1^{\text {st }}, 2^{\text {nd }}, 3^{\text {rd }}$, and $4^{\text {th }}$ classes in the Faculty of Health Sciences Department of Nutrition and Dietetics in Aydin Adnan Menderes University (ADU) were attended this analytical survey, and it was carried out through online Google docs forms. A total of 186 female (88.2\%) and 25 male (11.8\%) students attended the survey, while a few worked and studied. Even though there was no change in the number of students' meals between before and during the pandemic, the average body weight in $\mathrm{kg}$ increased $(\sim 1.26 \mathrm{~kg})$ during the pandemic. The average body weight (kg) of the students was increased by approximately $1.26 \mathrm{~kg}$ via pandemic, although there was no change in the number of meals of students before and during the pandemic. The intake of the food supplements, including Vitamin D, multivitamins, probiotics, did not change significantly, but the Vitamin C intake was significantly increased during the Covid-19 pandemic $(p<0.05)$. On the other hand, negative emotional moods were increased during the pandemic. Generally, students' eating habits were more effective than their demographic properties on depression and universities shaping essential roles in the students' food choices. Therefore, it is crucial for college students to take classes related to nutrition and improve their and other adults' knowledge of food and nutrition. Furthermore, mask, distance, and hygiene are the three preventive strategies on Covid-19 and other viral pandemics, and quality sleep, balanced eating habits, and physical activity should be promoted for a long-term healthy life.
\end{abstract}

Keywords: Dietetics; Student; Covid-19; Nutrition Habits; Factors

\section{Introduction}

In December 2019, patients who are the Huanan South China Seafood Market customers in Wuhan, Hubei Province, China, became infected with the third zoonotic human coronavirus (CoV) of the century. Having fever, trouble breathing, and bilateral lung infiltration are some of the severe symptoms of this viral pneumonia. Similar symptoms were also observed in other coronavirus incidents, including severe acute respiratory syndrome coronavirus 
(SARS-CoV) and Middle East respiratory syndrome coronavirus (MERS-CoV) infections [1]. According to World Health Organization (WHO), the CoV infected and killed $\sim 175$ and $\sim 3.9$ million people so far, respectively. The highest number of $\mathrm{CoV}$ cases has been seen in the United States and Europe, while Turkey is the $9^{\text {th }}$ country with the highest number of $\mathrm{CoV}$ cases ( $>5$ million) [2]. On March 10,2020 , the first CoV-19 case was confirmed in Turkey, and only seven days later, the first death was announced. Similar to the other countries in the world, some restrictions were announced in Turkey, including closing all the universities and schools, preventing visitors in the prisons, introducing travel restrictions to and from high-risk cities and countries, closing shopping malls, lockdown for people younger than 20 or older than 65 years old, and people with chronic diseases and immune system deficiency, forbidding traveling with private vehicles from and into the 31 largest cities, wearing a mask in common areas, lockdown for everybody over the weekends [3]. The Turkish government encouraged people to stay at home through the slogan "stay at the home" and in September 2020, they courage people to stay healthy through the slogan "mask, distance, and hygiene" [4]. During this process, we can say that our energy expenditure has decreased due to the restriction of our daily mobility, and an imbalance in our nutrition has emerged [5]. Also, changes and disturbance in the work routine because of the quarantine resulted in boredom and greater energy intake. Furthermore, constant reading or hearing about the Covid-19 pandemic increases the stress level of people, and it leads people to over-eating, especially comfort foods rich in sugar. Sugary foods cause food cravings, and they increase the risk of obesity and cardiovascular diseases beyond a chronic state of inflammation, which increases the risk for more severe complications of COVID-19 [6]. In the list of Nutrition Recommendations on the Coronavirus (Covid-19) of the Turkish Dietetic Association; it has been stated that the consumption of vegetables and fruits should be prioritized, good quality animal protein consumption should be considered, and that daily adequate vitamin and mineral intake should be provided [7]. Also, food supplements have started to be used because of adequate vitamin and mineral intake on the immune system [8]. In parallel, scientists have investigated the impact of the pandemic in terms of nutrition habits and food additive usage.

When the studies on the changes in the dietary habits of adults and students of the Covid pandemic are examined, these studies are generally based on the sociodemographic characteristics of the groups $[9,10]$ and the change of habits before and during the pandemic [11-13]. In a study conducted by Chi., et al. [14] on adolescents in China, the correlation between sociodemographic characteristics, physical activity, and Covid-19 correlated fear in determining mental health problems in youth during the Covid-19 pandemic was given. Furthermore, to the author's best knowledge, this is the first study to examine the correlation between all parameters, including sociodemographic characteristics of both students and individuals, dietary and dietary supplement use habits in the Covid-19 period, and mood changes. An article in which research about Covid-19 in Turkey was compiled determined that researches were generally about the diagnosis and treatment of Covid-19 [15]. Therefore, for timely prevention and effective intervention, we attempted to analyze associations between the factors (i.e., sociodemographic properties, emotional changes in the pandemic, etc.) with students' dietary habits and food supplement intake before and after the Covid 19 epidemic.

Nutrition science targets the foods consumed, the analysis of the composition of these foods, their interactions with each other, and their functions in the body. On the other hand, the science of dietetics is based on what kind of nutrition plan should be presented to prevent or treat diseases. It is crucial for individuals to stay healthy, create diet plans in case of illness, employ dietitians, and nutrition education, especially in the fields of preventive public health [16]. In a study conducted on university students receiving health education in different fields, the nutritional subscale values of nutrition and dietetics students were significantly higher than other students [17]. However, like all other university students, nutrition and dietetics students have been exposed to financial and emotional effects during the Covid-19. Effects, including changing location, distant education, psychological effects of the pandemic, anxiety, fear of harming their families, and decreased physical activity, can be given as examples [18].

Although there are studies on the nutritional habits of adults and students in the Covid-19 pandemic and the use of food supplements [9-11,19-22], there are no studies specifically focused on nutritional habits and supplements usage impacts on dietetic students in the viral epidemic. It is crucial to study this issue since nutrition and nutritional education are crucial for maintaining good public health and avoiding diseases. Researchers, universities, and health authorities interested in the impacts of COVID-19 on student nutrition habits, especially those interested in the link between context and food choice, may find this study useful. 


\section{Methods}

\section{Study design and population}

A cross-sectional study using an online survey was conducted in Turkey between June and July 2020 at the Aydın Adnan Menderes University. University students constitute the study population $\left(1^{\text {st }}, 2^{\text {nd }}, 3^{\text {rd }}\right.$, and $4^{\text {th }}$ classes $)$. The survey was developed based on literature [23-26]. The survey instrument included thirty-three questions, including socio-demographic characteristics, nutritional habits, and the use of food supplements before and during the pandemic.

The data was collected through Google forms. The general information section about the study followed by asking the students to confirm if they agreed to participate in the research. Furthermore, it was asked to reach researchers who wanted to get more detailed information about the study via email. The time to complete the questionnaire was determined as approximately 10-15 minutes.

\section{Sampling strategy}

A useful size of eligible students was invited to participate in the study through social media like WhatsApp groups and emails. The survey form for self-completion was mandatory for all the questions. Dietetic students' email addresses were obtained with official permission from the Aydin Adnan Menderes University (ADU) Dean of the Faculty of Health Sciences. All participants voluntarily participated in the study and were thus considered exempt from written informed consent. Those who agree to participate in the study will be included in the study by random sampling method. All the respondents were informed about the objectives of the study, including confidentiality of the data at the beginning of the survey. They consented to volunteer themselves in this completely anonymized, non-experimental, online study, and no identifiable information was gathered. The inclusion criteria were: a) participants aged 18 years and above; b) currently being a student at ADU Health Science Faculty, Nutrition and Dietetics Department in Turkey. Participants were excluded if they were: a) below 18 years of age; b) being a student extending enrollment at ADU Health Science Faculty, Nutrition and Dietetics Department c) not being a registered student in that department.

\section{Sample size}

The sample size was calculated as 187 with a $95 \%$ confidence level and a 5\% margin of error. Descriptive statistics were calcu- lated for the survey population. The universe of the research is 362. Since the research will be conducted online, it is planned to take the population as a sample to increase the power of the research due to the possibility of not participating in the research or loss. Therefore, all the $1^{\text {st }}$ (110 students), $2^{\text {nd }}$ (104 students), $3^{\text {rd }}$ (82 students), and $4^{\text {th }}$ class (66 students) students in the nutrition and dietetic department were invited to the research.

\section{Statistical design}

The data were analyzed using SPSS software, version 22 (IBM Corp, Armonk, NY, USA). Continuous variables were reported as mean ( \pm standard deviation [SD]), while categorical variables were reported as frequencies and percentages. Student t-test and one-way ANOVA tests were used to compare the mean knowledge scores between different demographic groups. To check the differences for the tested variables before and during the pandemic, the t-test was applied. A Chi-Square test was conducted to identify the source of significant variation within each group. A confidence interval of $95 \%(p<0.05)$ was applied to represent the statistical significance of the results, and the level of significance was predetermined as $5 \%$.

\section{Ethical considerations}

The Non-interventional Clinical Research Ethics Committee of the University approved the study protocol (Code number: 2020/027). The study was conducted under the principles of the Helsinki Declaration. As participation in the study was voluntary, the research ethics committee approved the consent waiver. Besides, the dean of ADU Health Faculty (June 22, 2020) and from the Ministry of Health of Turkey (June 26, 2020) required official permission was obtained.

\section{Results}

Participants' characteristics and habits before and during pandemic

The demographic characteristics of the students are shown in table 1 . A total of 211 students from the nutrition and dietetic department completed the online questionnaire and were included in the analysis. $186(88.2 \%)$ participants were female, while 25 $(11.8 \%)$ were male, and the average age of the students was 21 . Most of the students were not working but only studying nutrition and dietetics department $1^{\text {st }}(23.2 \%), 2^{\text {nd }}(23.2 \%), 3^{\text {rd }}(40.3 \%)$, and $4^{\text {th }}(13.3 \%)$ classes, while only a few of them $(2.9 \%)$ were both 
working and studying. The data related to the weight changes of the students before and during the pandemic are presented in Figure 1 . The average body weight $(\mathrm{kg})$ of the whole group before the pandemic was $59.1 \mathrm{~kg}$, and it increased approximately $1.26 \mathrm{~kg}$ during the pandemic. Only $6.8 \%$ of the students lost weight, and half gained weight during 90 days of the pandemic lockdown. The average height of the students was $165.8 \mathrm{~cm}$. Some habits of the students changed during the Covid-19 pandemic compared to before (Table 1). Specifically, $93.4 \%$ of the students reported changes in their daily/routine lives, $65.8 \%$ reported changes in their daily sleep time. For those students, their sleep time increased with pandemic and became 5-8 hours daily sleep in general. Furthermore, most of the students $(64.5 \%, \mathrm{n}: 136)$ reported that the increase in their sleep time also changed their food habits. However, most of the students continued to eat two- or three-times meals before and during the pandemic, and there was no change in their daily number of meals. Fruits and vegetables (22.9\%), chips snacks (20.4\%), and meat products $(20.4 \%)$ were reported as the most frequently consumed foods by the students during the pandemic. $63.5 \%$ of the students stated a change in their food intake during the pandemic; psychological reasons $(20.8 \%)$ and sleep pattern change, and increased film-series watching (16.8\%) were among the main reasons for the change in food intake during the pandemic. Additionally, most of the students (80.1\%, n:169) decreased their physical activities after the pandemic, while a very few $(6.6 \%, \mathrm{n}: 14)$ did not change their physical activity.

\begin{tabular}{|c|c|c|c|c|c|}
\hline Age, year, mean (\%) & 21 & $\begin{array}{c}\text { Gender, n (\%) } \\
\text { Woman } \\
\text { Man }\end{array}$ & $\begin{array}{l}88.2 \\
11.8\end{array}$ & Body weight, kg, mean & 59.1 \\
\hline $\begin{array}{l}\text { Class, } \mathrm{n}(\%) \\
\text { 1. class } \\
\text { 2. class } \\
\text { 3. class } \\
\text { 4. class }\end{array}$ & $\begin{array}{l}23.2 \\
23.2 \\
40.3 \\
13.3\end{array}$ & $\begin{array}{l}\text { Student } \\
\text { Other }\end{array}$ & $\begin{array}{c}97.2 \\
2.9\end{array}$ & Height, $\mathrm{cm}$, average & 165.8 \\
\hline \multirow{2}{*}{$\begin{array}{c}\text { Routine life change during } \\
\text { the pandemic (\%) } \\
\text { Yes } \\
\text { No }\end{array}$} & \multirow[b]{2}{*}{$\begin{array}{c}93.4 \\
6.6\end{array}$} & \multirow{2}{*}{ 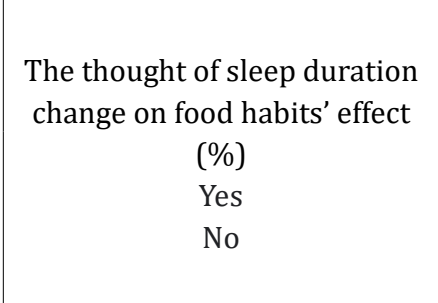 } & \multirow[b]{2}{*}{$\begin{array}{l}64.5 \\
35.5\end{array}$} & $\begin{array}{l}\text { How many days he/she has been at home } \\
\text { during the pandemic (days), average }\end{array}$ & 90 \\
\hline & & & & $\begin{array}{l}\text { Sleep time before pandemic }(\%) \\
\qquad 5 \text { hours } \\
5-8 \text { hours } \\
>8 \text { hours }\end{array}$ & $\begin{array}{c}4.0 \\
65.9 \\
23.5\end{array}$ \\
\hline $\begin{array}{l}\text { Food supplement use dur- } \\
\text { ing the pandemic (\%) } \\
\text { Yes } \\
\text { No }\end{array}$ & $\begin{array}{l}13.3 \\
86.7\end{array}$ & $\begin{array}{l}\text { Food supplement use before the } \\
\text { pandemic (\%) } \\
\text { Yes } \\
\text { No }\end{array}$ & $\begin{array}{l}12.4 \\
80.1\end{array}$ & $\begin{array}{c}\text { Change in sleep time after pandemic (\%) } \\
\text { Sleep time increased } \\
\text { Sleep time hasn't changed } \\
\text { Sleep time decreased }\end{array}$ & $\begin{array}{l}62.6 \\
23.7 \\
13.7\end{array}$ \\
\hline \begin{tabular}{|c|} 
Food supplements usage \\
during the pandemic (\%) \\
D vitamin \\
Probiotic \\
Multivitamin \\
C vitamin \\
Zinc \\
Selenium \\
Propolis \\
Collagen \\
Black elderberry \\
Other
\end{tabular} & $\begin{array}{c}20.3 \\
9.4 \\
15.6 \\
14.1 \\
4.7 \\
1.6 \\
3.1 \\
0 \\
4.7 \\
26.6\end{array}$ & $\begin{array}{c}\text { Food supplements usage before } \\
\text { the pandemic (\%). } \\
\text { D vitamin } \\
\text { Probiotic } \\
\text { Multivitamin } \\
\text { C vitamin } \\
\text { Zinc } \\
\text { Selenium } \\
\text { Propolis } \\
\text { Collagen } \\
\text { Black elderberry } \\
\text { Other }\end{array}$ & $\begin{array}{c}21 \\
21 \\
8.1 \\
4.8 \\
4.8 \\
4.8 \\
4.8 \\
3.2 \\
0 \\
27.4\end{array}$ & $\begin{array}{l}\text { The most frequently consumed food and } \\
\text { food groups during the pandemic (\%) } \\
\text { Vegetables and fruits } \\
\text { Meat } \\
\text { Cips and snack } \\
\text { Grain group } \\
\text { Milk and dairy products }\end{array}$ & $\begin{array}{l}22.9 \\
20.4 \\
20.4 \\
18.7 \\
17.7\end{array}$ \\
\hline
\end{tabular}

Citation: Ayse Demet Karaman., et al. "Evaluating the Impact of Covid-19 Pandemic on Nutritional Habits and Supplementary Food Use in Dietetic Students". Acta Scientific Nutritional Health 5.12 (2021): 81-95. 


\begin{tabular}{|c|c|c|c|c|c|}
\hline \begin{tabular}{|} 
How many main meals \\
are fed after the pandemic \\
$(\%)$ \\
Meal 1 \\
Meal 2 \\
Meal 3 \\
$>3$ Meal
\end{tabular} & $\begin{array}{c}3.1 \\
40.3 \\
31.9 \\
18.1\end{array}$ & \begin{tabular}{|c|} 
Food intake change during the \\
pandemic(\%) \\
Increased \\
Decreased \\
Not changed
\end{tabular} & $\begin{array}{c}63.5 \\
19.4 \\
117.1\end{array}$ & $\begin{array}{l}\text { The effect of emotional change on food } \\
\text { intake during the pandemic (\%) } \\
\text { Increased } \\
\text { Decreased } \\
\text { Not changed }\end{array}$ & $\begin{array}{l}21.3 \\
55.9 \\
22.7\end{array}$ \\
\hline \begin{tabular}{|} 
How many main meals are \\
fed before the pandemic \\
$(\%)$ \\
Meal 1 \\
Meal 2 \\
Meal 3 \\
$>3$ Meal
\end{tabular} & $\begin{array}{c}1.8 \\
37.2 \\
48.2 \\
6.3\end{array}$ & \begin{tabular}{|} 
Purpose food supplement usage \\
during the pandemic (\%) \\
Strengthen immunity \\
Prevent fatigue \\
Physical performance \\
Mental performance \\
Weight control \\
Stress disorders \\
Joint problems \\
Sleeping disorders
\end{tabular} & $\begin{array}{l}37.5 \\
19.0 \\
11.1 \\
12.0 \\
6.0 \\
6.5 \\
2.3 \\
5.6\end{array}$ & $\begin{array}{c}\text { Reasons for change in food intake during } \\
\text { the pandemic(\%) } \\
\text { Psychological reasons } \\
\text { Sleep pattern change } \\
\text { Increasing movie and TV series } \\
\text { watching rate } \\
\text { Increasing social media usage } \\
\text { Feeling blocked } \\
\text { Loneliness feeling } \\
\text { Insecurity } \\
\text { Increased game play rate }\end{array}$ & $\begin{array}{l}20.8 \\
20.4 \\
16.8 \\
\\
12.6 \\
10.2 \\
9.2 \\
5.4 \\
4.8\end{array}$ \\
\hline \begin{tabular}{|} 
Change in physical activity \\
level after the pandem- \\
ic(\%) \\
Decreased \\
Increased \\
Not changed
\end{tabular} & $\begin{array}{c}80.1 \\
13.3 \\
6.6\end{array}$ & \begin{tabular}{|} 
Through which source did the \\
food supplements began to use \\
during the pandemic? (\%) \\
Doctor \\
Family/Friends etc \\
Internet \\
Pharmacist \\
TV
\end{tabular} & $\begin{array}{c}34.6 \\
21.2 \\
15.4 \\
26.9 \\
1.9\end{array}$ & $\begin{array}{l}\text { Emotion feeling changes in during the } \\
\text { pandemic (\%) } \\
\text { Anxiety } \\
\text { Sadness } \\
\text { Fear } \\
\text { Disgusting } \\
\text { Fear } \\
\text { Happiness } \\
\text { Insecurity } \\
\text { Blocked feeling } \\
\text { Boredom }\end{array}$ & $\begin{array}{c}18.3 \\
13.5 \\
20.9 \\
11.5 \\
3.9 \\
10.4 \\
1.9 \\
6.7 \\
12.9\end{array}$ \\
\hline
\end{tabular}

Table 1: Demographic Characteristics, Dietary Habits and Supplementary Food Use of the Participants $(n=211)$.

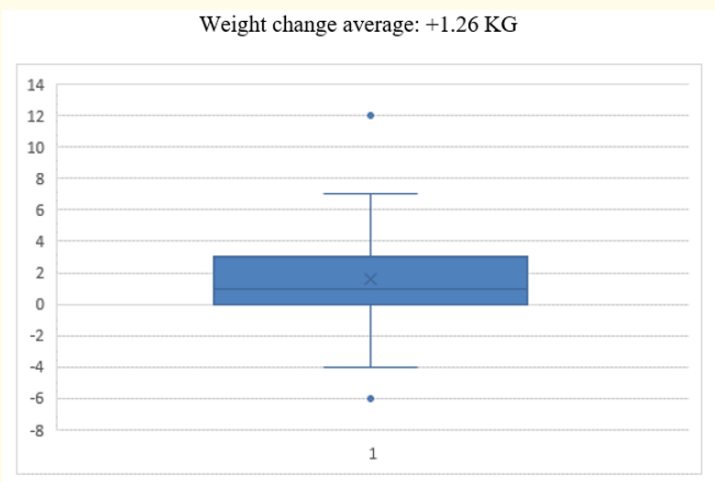

Graphic 1. Body Weight Changes of Students During the Covid19 Pandemic

Figure 1: Body Weight Changes of Students During the Covid19 Pandemic.
Most participants reported that they did not use food supplements before (\% 80.1, n:181) and during (\% 86.7, n:183) the pandemic. Vitamins, including D, C, and multivitamins, were among the most common supplements before the pandemic. In addition, they reported they started to use the food supplements during the pandemic with advice from the doctors (34.6\%) and pharmacists (26.9\%) to strengthen their immune system (37.5\%) and prevent fatigue (19.0\%) (Table 1).

Based on the data in Table 1, emotional changes effectively increased food intake in more than half (55.9\%) of the students during the pandemic. Table 1 also showed that the most common emotional changes were fear (20.9\%), anxiety (18.3\%), sadness (13.5\%), and boredom (12.9\%), respectively, during the pandemic. 
Correlations between characteristics and habits before and during pandemic

In this study, we explored any changes in nutritional habits and food supplement intake before and during the Covid-19 pandemic between the students, and relatively few significant differences have been found. When examining the influence in changes of nutritional habits and food supplement intake during the pandemic compared to before, we found that there was a statistically significant difference between the averages only in the use of vitamin $\mathrm{C}$ supplements during the Covid-19 pandemic compared to before (Table 2) $(\mathrm{p}<0.05)$. Vitamin $\mathrm{C}$ use also changed significantly during pandemics compared to before.

\begin{tabular}{|l|c|c|c|c|c|}
\hline & $\begin{array}{c}\text { Number } \\
\text { (n) }\end{array}$ & Mean & $\begin{array}{c}\text { Standard } \\
\text { deviation }\end{array}$ & t & Sig. (p) \\
\hline $\begin{array}{l}\text { Vitamin C } \\
\text { usage before } \\
\text { pandemic \& } \\
\text { Vitamin C } \\
\text { usage during } \\
\text { pandemic }\end{array}$ & 211 & -.02844 & .19309 & -2.139 & .034 \\
\hline
\end{tabular}

Table 2: The Relationship Between Students' Vitamin C

Supplement Intake Before and After the Covid19 Pandemic.

The relationships between the use of vitamin $C$ supplements before and during the pandemic and other parameters are given in table 3 ( $\mathrm{p}<0.05)$. A statistically significant negative correlation was found between the students' vitamin $C$ supplements use before the pandemic and their classes $(p<0.05)$. It can be said that the upper-grade students used less vitamin $C$ before the pandemic. There was also a statistically significant relationship between the use of vitamin $C$ supplements before the pandemic and the use of some parameters, including meat consumption, physical activity changes, etc. $(p<0.05)$. Similarly, in the use of vitamin $C$ supplements before the pandemic, there was a significant relationship between the sadness and disgust of the students in the pandemic. As expected, multivitamin supplements during the pandemic were effective on vitamin $\mathrm{C}$ usage during and before the pandemic. It means that whether it is a pandemic, students may take multivitamins between vitamin $\mathrm{C}$. There was a significant negative relationship between the vitamin $\mathrm{C}$ use during the pandemic and sleep time change (.149). On the other hand, there was a positive statistically significant relationship between the use of vitamin $C$ supplements during the pandemic and vitamin $\mathrm{D}$ and probiotic intake during the pandemic $(\mathrm{p}<0.05)(.141)$ (Table 3).

\begin{tabular}{|c|c|c|}
\hline Parameter & Parameter & p value \\
\hline \multirow{9}{*}{$\begin{array}{l}\text { Vitamin C } \\
\text { Supplement use before } \\
\text { pandemic }\end{array}$} & Class & $-.175^{*}$ \\
\hline & \begin{tabular}{|c|} 
Meat group consumption \\
relationship during the \\
pandemic
\end{tabular} & $.135^{*}$ \\
\hline & $\begin{array}{c}\text { Change in physical activity } \\
\text { during the pandemic }\end{array}$ & $.172^{*}$ \\
\hline & $\begin{array}{c}\text { How many main meals } \\
\text { were fed after the } \\
\text { pandemic }\end{array}$ & $.143^{*}$ \\
\hline & $\begin{array}{c}\text { The use of food } \\
\text { supplements to strengthen } \\
\text { immunity in the pandemic }\end{array}$ & $.152^{*}$ \\
\hline & $\begin{array}{c}\text { The effect of mood } \\
\text { changes on food intake } \\
\text { during the pandemic }\end{array}$ & $-.151^{*}$ \\
\hline & Pandemic disgust & $.162^{*}$ \\
\hline & Pandemic sadness & $-.138^{*}$ \\
\hline & $\begin{array}{c}\text { Use of multivitamin } \\
\text { supplements during the } \\
\text { pandemic }\end{array}$ & $.162^{*}$ \\
\hline \multirow{4}{*}{$\begin{array}{l}\text { Vitamin C } \\
\text { Supplement use during } \\
\text { pandemic }\end{array}$} & $\begin{array}{c}\text { Use of multivitamin } \\
\text { supplements during the } \\
\text { pandemic }\end{array}$ & $.174^{*}$ \\
\hline & $\begin{array}{l}\text { Sleep time change after } \\
\text { pandemic }\end{array}$ & $-.149 *$ \\
\hline & $\begin{array}{c}\text { Vitamin D supplement use } \\
\text { before pandemic }\end{array}$ & $.141^{*}$ \\
\hline & $\begin{array}{c}\text { Probiotic supplement use } \\
\text { before pandemic }\end{array}$ & $.141^{*}$ \\
\hline
\end{tabular}

Table 3: Correlations between Vitamin C Usage on Students' Eating Habits and Food Supplements Before and During Pandemic

$$
(\mathrm{n}=211) \text {. }
$$

*Correlation is significant at the 0.05 .

The relationship between demographics and other parameters before and during pandemic were given in Table 4. A statistical evaluation was made to determine whether the difference between the student classes and the Covid-19 epidemic nutrition was influential in the students' nutritional habits and food supplement intake $(p<0.05)$. There was a significant difference between the students' classes and the effect of sleep time change on food intake, and this relationship was positive $(p<0.05)$. Additionally, since the classes of the students increased, the use of vitamin $C$, collagen, 
selenium supplements before the pandemic decreased, and the statistically significant level of this situation was found to be strong $(\mathrm{p}$ $<0.05)$. As the class of the students increased, anxiety feeling in the pandemic increased significantly $(\mathrm{p}<0.05)$ (Table 4).

\begin{tabular}{|c|c|c|}
\hline & Parameter & p value \\
\hline \multirow{6}{*}{ Class } & $\begin{array}{l}\text { The effect of sleep duration change on } \\
\text { food intake }\end{array}$ & $.148^{*}$ \\
\hline & $\begin{array}{l}\text { Change in sleep patterns with increased } \\
\text { food intake }\end{array}$ & $-.148^{*}$ \\
\hline & $\begin{array}{l}\text { Vitamin C supplement use before pan- } \\
\text { demic }\end{array}$ & $-.175^{*}$ \\
\hline & $\begin{array}{l}\text { Use of collagen supplements before the } \\
\text { pandemic }\end{array}$ & $-.142^{*}$ \\
\hline & $\begin{array}{l}\text { Selenium supplement use before pan- } \\
\text { demic }\end{array}$ & $-.175^{*}$ \\
\hline & Pandemic anxiety & $.148^{*}$ \\
\hline \multirow[t]{7}{*}{ Age } & Body weight & $.153^{*}$ \\
\hline & $\begin{array}{c}\text { The relationship between consumption of } \\
\text { snacks (chips, chocolate, etc.) during the } \\
\text { pandemic }\end{array}$ & $-.145^{*}$ \\
\hline & Sleep time change after pandemic & $.164^{*}$ \\
\hline & $\begin{array}{l}\text { Change in sleep patterns with increased } \\
\text { food intake }\end{array}$ & $-.142^{*}$ \\
\hline & $\begin{array}{l}\text { The relationship between increased food } \\
\text { intake and feeling of loneliness }\end{array}$ & $-.138^{*}$ \\
\hline & Pandemic sadness & $-.164^{*}$ \\
\hline & Pandemic boredom & $-.141^{*}$ \\
\hline \multirow[t]{7}{*}{ Gender } & $\begin{array}{l}\text { The relationship between increasing food } \\
\text { intake and watching TV series/movies }\end{array}$ & $-.138^{*}$ \\
\hline & Body weight change during the pandemic & $.155^{*}$ \\
\hline & $\begin{array}{l}\text { Milk and dairy group consumption rela- } \\
\text { tionship during the pandemic }\end{array}$ & $.147^{*}$ \\
\hline & $\begin{array}{l}\text { In the pandemic, food supplement for } \\
\text { physical performance purposes }\end{array}$ & $.146^{*}$ \\
\hline & $\begin{array}{l}\text { How many main meals are fed after the } \\
\text { pandemic }\end{array}$ & $.172^{*}$ \\
\hline & Pandemic disgust & $-.163^{*}$ \\
\hline & $\begin{array}{l}\text { Thought of the effect of sleep time change } \\
\text { on food habits }\end{array}$ & $-.157^{*}$ \\
\hline \multirow[t]{5}{*}{ Height } & Class & $.147^{*}$ \\
\hline & $\begin{array}{l}\text { Probiotic supplement use before pan- } \\
\text { demic }\end{array}$ & $-.138^{*}$ \\
\hline & $\begin{array}{l}\text { Selenium supplement use during the } \\
\text { pandemic }\end{array}$ & $.138^{*}$ \\
\hline & Pandemic anxiety & $-.142^{*}$ \\
\hline & Pandemic fear & $-.160^{*}$ \\
\hline
\end{tabular}

\begin{tabular}{|l|c|c|}
\hline $\begin{array}{l}\text { Body } \\
\text { weight }\end{array}$ & $\begin{array}{c}\text { Cereal group consumption during the } \\
\text { pandemic }\end{array}$ & $.162^{*}$ \\
\cline { 2 - 3 } & $\begin{array}{c}\text { The effect of mood changes on food intake } \\
\text { during the pandemic }\end{array}$ & $.161^{*}$ \\
\hline
\end{tabular}

Table 4: Correlations Between Demographics and Eating Habits/ Food Supplements Before and During Pandemic of Students ( $\mathrm{n}=211)$.

*Correlation is significant at the 0.05 .

Since student's age increased in the pandemic, their body weight also increased. Therefore, senior students gained more weight in the pandemic. On the other hand, it was observed that as the age of the students increased, they consumed fewer snacks (chips, chocolate, etc.) ( $\mathrm{p}<0.05)$. Additionally, students with a lower age group were more bored, lonely, and sad during the pandemic (Table 4).

The relationship between the nutritional habits of the students (1: Female, 2: Male) during the pandemic and their intake of food supplements depending on their gender was given in (Table 4). In the pandemic, it has been determined that male students have higher body weight changes, use of food supplements for physical performance, and consumption of dairy products due to positive correlation $(p<0.05)$. As expected, the height of the students increased, students' classes increased $(p<0.05)$. It was found that when the height of the students increased, their feelings of anxiety and fear decreased in the pandemic, and there was a statistically significant relationship between these parameters. Similarly, as the height of the students increased, selenium supplements usage during the pandemic increased, but the probiotic supplements usage decreased $(p<0.05)$. A statistically significant relationship was found between the bodyweight of the students and the consumption of the cereal group during the pandemic and the effect of emotional change on food intake during the pandemic. The consumption of cereal foods was a factor in the students' weight gain during the pandemic (Table 4).

Table 5 highlights that according to the correlations between the effects of students' emotional changes and eating habits during the Covid-19 pandemic, generally, depression emotions are significantly more related to eating habits than demographic properties $(\mathrm{p}<0.05)$. There was a mostly positive significant difference between all parameters (Table 5). This is consistent with a covid related drop in the overall mood and wellness behavior of dietetic 
students. It was observed that happiness scores during pandemic

pandemic $(\mathrm{p}<0.05)$. positively related to food supplement and probiotics intake before

\begin{tabular}{|c|c|c|c|c|c|}
\hline \multirow{6}{*}{$\begin{array}{l}\text { Pandemic anxiety } \\
\text { feeling }\end{array}$} & Class & $.148^{*}$ & \multirow{3}{*}{$\begin{array}{l}\text { Pandemic boredom } \\
\text { feeling }\end{array}$} & Age & $-.141^{*}$ \\
\hline & Height & $-.142^{*}$ & & $\begin{array}{c}\text { Increased food intake and feeling } \\
\text { of loneliness }\end{array}$ & $.164^{*}$ \\
\hline & $\begin{array}{l}\text { Increasing food intake } \\
\text { and watching TV } \\
\text { series/movies }\end{array}$ & $.174^{*}$ & & $\begin{array}{c}\text { Change in physical activity during } \\
\text { the pandemic }\end{array}$ & $-.152^{*}$ \\
\hline & $\begin{array}{l}\text { Vegetable and fruit } \\
\text { group consumption } \\
\text { during the pandemic }\end{array}$ & $.169^{*}$ & & $\begin{array}{l}\text { Use of collagen supplements } \\
\text { before the pandemic }\end{array}$ & $.155^{*}$ \\
\hline & Pandemic boredom & $.141^{*}$ & $\begin{array}{l}\text { Pandemic insecu- } \\
\text { rity feeling }\end{array}$ & $\begin{array}{l}\text { Using food supplements with } \\
\text { internet advice during the } \\
\text { pandemic }\end{array}$ & $.149^{*}$ \\
\hline & Pandemic disgust & $.151^{*}$ & & $\begin{array}{l}\text { The effect of mood changes on } \\
\text { food intake during the pandemic }\end{array}$ & $-.153^{*}$ \\
\hline \multirow{6}{*}{$\begin{array}{l}\text { Pandemic sadness } \\
\text { feeling }\end{array}$} & Age & $-.164^{*}$ & \multirow{6}{*}{$\begin{array}{l}\text { Pandemic fear } \\
\text { feeling }\end{array}$} & Height & $-.160^{*}$ \\
\hline & $\begin{array}{l}\text { Increasing food intake } \\
\text { and watching TV } \\
\text { series/movies }\end{array}$ & $.156^{*}$ & & $\begin{array}{l}\text { Increased nutrient intake and } \\
\text { increased gaming }\end{array}$ & $.168^{*}$ \\
\hline & $\begin{array}{l}\text { Routine life change } \\
\text { during the pandemic }\end{array}$ & $.152^{*}$ & & $\begin{array}{c}\text { Increased food intake and feeling } \\
\text { of loneliness }\end{array}$ & $.168^{*}$ \\
\hline & $\begin{array}{c}\text { Consumption of snacks } \\
\text { (chips, } \\
\text { chocolate, etc.) } \\
\text { during the } \\
\text { pandemic } \\
\end{array}$ & $.139 *$ & & Sleep time change after pandemic & $-.149 *$ \\
\hline & $\begin{array}{c}\text { Vitamin C } \\
\text { supplement use } \\
\text { before pandemic }\end{array}$ & $-.138^{*}$ & & $\begin{array}{l}\text { Using food supplements with } \\
\text { doctor's advice during the } \\
\text { pandemic }\end{array}$ & $.175^{*}$ \\
\hline & $\begin{array}{c}\text { The feeling of happiness } \\
\text { and the pandemic }\end{array}$ & $.152^{*}$ & & $\begin{array}{l}\text { Using food supplements to } \\
\text { strengthen immunity in the } \\
\text { pandemic }\end{array}$ & $.140^{*}$ \\
\hline \multirow{3}{*}{$\begin{array}{l}\text { The feeling of } \\
\text { happiness and the } \\
\text { pandemic }\end{array}$} & $\begin{array}{c}\text { The idea of the effect of } \\
\text { sleep } \\
\text { duration change on food } \\
\text { habits }\end{array}$ & $.147^{*}$ & \multirow{3}{*}{$\begin{array}{l}\text { Pandemic blocked } \\
\text { feeling of feeling }\end{array}$} & $\begin{array}{c}\text { Use of multivitamin supplements } \\
\text { during the pandemic }\end{array}$ & $.156^{*}$ \\
\hline & $\begin{array}{l}\text { Food supplement use } \\
\text { before } \\
\text { pandemic }\end{array}$ & $.141^{*}$ & & $\begin{array}{l}\text { Use of probiotic supplements } \\
\text { during the pandemic }\end{array}$ & $.155^{*}$ \\
\hline & $\begin{array}{l}\text { Probiotic supplement } \\
\text { use before pandemic }\end{array}$ & $.141^{*}$ & & $\begin{array}{l}\text { Vitamin D supplement use before } \\
\text { pandemic }\end{array}$ & $.151^{*}$ \\
\hline
\end{tabular}




\begin{tabular}{|c|c|c|c|c|c|}
\hline \multirow{9}{*}{$\begin{array}{l}\text { Pandemic disgust } \\
\text { feeling }\end{array}$} & $\begin{array}{l}\text { Change in sleep time } \\
\text { after pandemic }\end{array}$ & $-.157^{*}$ & \multirow{9}{*}{$\begin{array}{l}\text { Pandemi süresince } \\
\text { duygu değişiminin } \\
\text { besin alımına etkisi }\end{array}$} & Body weight & $.161^{*}$ \\
\hline & $\begin{array}{l}\text { Vegetable and fruit } \\
\text { group consumption } \\
\text { during the pandemic }\end{array}$ & $.138^{*}$ & & $\begin{array}{l}\text { Change in sleep patterns with } \\
\text { increased food intake }\end{array}$ & $.149^{*}$ \\
\hline & $\begin{array}{c}\text { How many main meals } \\
\text { were fed before the } \\
\text { pandemic }\end{array}$ & $.139 *$ & & $\begin{array}{l}\text { Increased food intake and } \\
\text { increased social media use }\end{array}$ & $.161^{*}$ \\
\hline & $\begin{array}{l}\text { Vitamin C supplement } \\
\text { use before pandemic }\end{array}$ & $.162^{*}$ & & $\begin{array}{l}\text { Increased nutrient intake and } \\
\text { increased gaming }\end{array}$ & $.137^{*}$ \\
\hline & $\begin{array}{l}\text { Zinc supplement use } \\
\text { before pandemic }\end{array}$ & $.162^{*}$ & & $\begin{array}{l}\text { Vegetable and fruit group } \\
\text { consumption during the } \\
\text { pandemic }\end{array}$ & $-.162^{*}$ \\
\hline & $\begin{array}{l}\text { Selenium supplement } \\
\text { use before pandemic }\end{array}$ & $.162^{*}$ & & $\begin{array}{c}\text { Vitamin C supplement use before } \\
\text { pandemic }\end{array}$ & $-.151^{*}$ \\
\hline & $\begin{array}{l}\text { Probiotic supplement } \\
\text { use before pandemic }\end{array}$ & $.151^{*}$ & & $\begin{array}{c}\text { Use of collagen supplements } \\
\text { before the pandemic }\end{array}$ & $-.163^{*}$ \\
\hline & \multirow{2}{*}{$\begin{array}{c}\text { Using food supplements } \\
\text { to strengthen immunity } \\
\text { in the pandemic }\end{array}$} & \multirow{2}{*}{$.146^{*}$} & & $\begin{array}{c}\text { Selenium supplement use before } \\
\text { the pandemic }\end{array}$ & $-.151^{*}$ \\
\hline & & & & $\begin{array}{l}\text { Multivitamin supplement use } \\
\text { before the pandemic }\end{array}$ & $-.144^{*}$ \\
\hline \multirow{5}{*}{$\begin{array}{l}\text { Pandemic anger } \\
\text { feeling }\end{array}$} & $\begin{array}{c}\text { The relationship } \\
\text { between increased food } \\
\text { intake and feelings of } \\
\text { insecurity }\end{array}$ & $.156^{*}$ & \multirow{5}{*}{$\begin{array}{l}\text { Pandemic anger } \\
\text { feeling }\end{array}$} & $\begin{array}{l}\text { Using food supplements for } \\
\text { physical performance in the } \\
\text { pandemic }\end{array}$ & $.163^{*}$ \\
\hline & $\begin{array}{l}\text { Relationship between } \\
\text { increased food intake } \\
\text { and feeling inhibited }\end{array}$ & $.174^{*}$ & & $\begin{array}{l}\text { Using food supplements for body } \\
\text { weight control in the pandemic }\end{array}$ & $.170^{*}$ \\
\hline & $\begin{array}{c}\text { Using food supplements } \\
\text { with doctor's advice } \\
\text { during the pandemic }\end{array}$ & $.173^{*}$ & & $\begin{array}{l}\text { Using food supplements for joint } \\
\text { problems in the pandemic }\end{array}$ & $.175^{*}$ \\
\hline & \multirow{2}{*}{$\begin{array}{c}\text { How many main meals } \\
\text { were fed before the } \\
\text { pandemic }\end{array}$} & \multirow{2}{*}{$.156^{*}$} & & $\begin{array}{l}\text { Zinc supplement use before the } \\
\text { pandemic }\end{array}$ & $.135^{*}$ \\
\hline & & & & $\begin{array}{c}\text { Probiotic supplement use before } \\
\text { the pandemic }\end{array}$ & \\
\hline
\end{tabular}

Table 5: The Level of Correlation Between the Effects of Students' Emotional Changes on Students' Eating Habits and Food Supplements During the Pandemic $(\mathrm{n}=211)$.

*Correlation is significant at the 0.05 .

\section{Discussion}

To our best knowledge, this is the first study that investigated habits in dietetic students with nutritional changes during the pandemic. This study has been designed to examine the eating habits and supplementary food use of the university students who stay at home during the pandemic that has affected all humanity. The present study mainly included females (88.2\%), averagely 21 years old, and mostly $3^{\text {rd }}(40.3 \%)$ class nutrition and dietetic students. Almost all students just were studying (Table 1). After the pandemic, $93.4 \%$ of these students passed to distance education. College 
students stay at home for 90 days $1.26 \mathrm{~kg}$ body weight, increasing at the end of the period (Figure 1).

The bodyweight of only $6.8 \%$ of students did not change for 90 days pandemic lockdown, while almost half of the students increased. Covid-19 increased length of stay at home with the epidemic a virus-safe environment for students, increasing food intake and decreased physical activity levels. Several factors, such as those related to lifestyles, like physical activity decrease (80.1\%), daily sleep time (65.8\%), and eating habits (63.5\%) increases, may have influenced the change the body weight. Weight gain was an outcome of the pandemic reported by other authors for university students (Table 1). Ünal., et al. [11] surveyed nursing students, with the majority being women (84.1\%). They reported that most of the students (68.3\%) observed an increase in their body weight. In the same study, weight changes were related to physical activity, house environment, and psychological desire to eat. The outcomes reflected the results of the present research. Therefore, although there was no change in the number of meals of the students before and after the pandemic, their sleep time $64.5 \%$ (n: 136) increased, and psychological reasons (20.8\%) were the main reason for this increase in food intake. In this sense, the possibility of minor increases in body weight over brief periods being lasting and leading to long-term weight gain should be considered [27]. It is among the suggestions developed due to Covid-19, mainly for strengthening, balance and control, stretching exercises with walking at home, squats, sit-ups, and yoga through the internet, mobile technologies, and television [28,29]. WHO suggests all ages 18-64 for healthy individuals $150 \mathrm{~min} /$ week moderate or $75 \mathrm{~min} /$ week of vigorous physical activity [30].

Consumption of fiber, whole grains, unsaturated fats and antioxidants, adequate intake of vitamins A, C, D, E, and B group, omega-3 polyunsaturated fatty acids, selenium, zinc, and iron to reduce COVID-19 susceptibility and its long-term complications, avoiding the consumption of saturated fatty acids, sugar, and refined carbohydrates and paying attention to healthy eating habits are of great importance for maintaining immune function [21].

We observed the most frequently consumed foods like vegetables and fruits (22.9\%), which are health-promoting products recommended by The Food and Agriculture Organization during the Covid-19 pandemic [31]. This survey also revealed that chips snacks $(20.4 \%)$, and meat products $(20.4 \%)$ were frequently con- sumed by students. However, when comparing these data with other studies developed using university students and adults, bread and other bakery products such as white bread, pastry, and pie were the most frequently eaten in Turkey $[5,22,32,33]$. Considering the nutritional status of the Turkish people, the primary food is bread and other grain products; the main factors for these results in our study may be related to dietetic students knowing training in the field of health, nutrition, food composition. Therefore, this finding could indicate specific characteristics of the population investigated rather than a distinctive trait of the pandemics. In Poland study, vegetables and bakery products were the most consumed foods in adults [20].

During the COVID-19 pandemic, to create a strong immunity, having a balanced diet, taking vitamin D supplements, ample fluid intake is critical [12]. When examining the food supplements usage during the lockdown compared to before, we found that generally, students did not use (80.1\% and $86.7 \%)$. In this study, we would have expected an increase in food supplements diversity and levels, but only $13.3 \%$ of the students reported that they had used supplements such as vitamin D, multivitamins, and vitamin $\mathrm{C}$ during the Covid-19 pandemic to enhance the immune system (34.6\%) thus they could protect themselves from the disease with the advice of doctors (34.6\%) and pharmacists (Table 1). Overall, regardless of the time point, the use of dietary supplements in this study was lower than other researches $[10,20,22]$. However, this study was conducted in the early stages of the pandemic lockdown in Turkey; these outcomes should not be considered a result of Covid-19. Additional long-term research is needed, including the use of herbal products. There are publications that high doses of vitamin C supplementation can be used in CoV-positive cases [34-36], but it has not been conclusively proven to be protective against the disease. Studies have shown that vitamin $C$ helps to prevent lower respiratory tract infection susceptibility under certain conditions, while COVID-19 may cause lower respiratory tract infection [37]. In another study, it has been reported that countries with low average vitamin D levels had a higher number of Covid-19 cases [38].

Lockdown can limit the spread of Covid-19. During Covid-19, physical health can be maintained through social distancing, masks, and handwashing [39]. Furthermore, factors such as an increase in food prices, unemployment, decreased income, living in large families can be adversely affected [21] food intake and mental stress. Also, more COVID-fear was significantly associated with

Citation: Ayse Demet Karaman., et al. "Evaluating the Impact of Covid-19 Pandemic on Nutritional Habits and Supplementary Food Use in Dietetic Students". Acta Scientific Nutritional Health 5.12 (2021): 81-95. 
higher insomnia, depression, and anxiety [14]. Therefore, students at all academic levels (high school, undergraduate, and postgraduate) demonstrated negative feelings, including anxiety, depression, tiredness, stress, overwhelm, and low energy levels, because of the lockdown [40]. Because of the Covid-19 related stress eating and changes in the nutritional behavior should be prioritized these days because many people are experiencing an increase in their appetite and having many breakfasts and dinners each day [41]. For this reason, when the studies on the effects of emotional states such as depression, anxiety, and stress on nutrition in the Covid-19 pandemic are examined, it is seen that individuals increase their food intake. A study conducted on 341 individuals between the ages of 18-65 living in Turkey determined that a large part of the individuals had changes in their moods due to Covid-19 and that these changes increased their food intake [22]. Consistent with other Covid-19 studies, the present study shows that dietetic students were reported with fear (20.9\%), anxiety (18.3\%), sadness (13.5\%), and boredom (12.9\%) with increasing food intake (55.9\%) (Table 1). Our results suggest that almost half of the dietetic students do not perceive that strengthening the immune system through food additives consumption could help them limit Covid-19's disease contagion, although they were under mental stress due to the pandemic. As a result, there is an increase in emotional changes and increase in food intake, associated with physical inactivity and consequently weight gain, as reported by the university students in this research and other studies $[21,42,43]$. We can say that these results were taken from the study because the Covid-19 epidemic has many new, scary, and unknown aspects, and people are indifferent rushes. In addition, it is thought that the negative emotional impact is more since the majority of the students (88\%) participating in our research is female. Bonding the college students and the academic personnel through social solidarity can generate physical and emotional support.

The correlations with all characteristics and habits interested in this study were given in Tables 2-5, respectively. According to table 2 , compared to before the pandemic, dietetic students' vitamin $\mathrm{C}$ consumption varies significantly $(\mathrm{p}<0.05)$. This result is partially supported by a Covid study indicating that nursing students were statistically taking more $\mathrm{C}$ vitamins during the pandemic than before, more likely to increase immune system [11]. Vitamin C regulates the function of the human immune system by supporting various aspects of both the innate and adaptive immune sys- tem, including epithelial barrier function, chemotaxis and antimicrobial activities of phagocyte cells, the function of NK cells, and lymphocyte proliferation and differentiation. In humans, vitamin $\mathrm{C}$ deficiency is associated with impaired immune responses and increased susceptibility to infection, while vitamin C supplementation appears beneficial for preventing and treating infections [44]. In addition, there are publications that high doses of vitamin $\mathrm{C}$ supplements can be used in CoV-positive cases, but it has not been conclusively proven to be protective against the disease $[45,46]$.

For this reason, the use of vitamin D, probiotics, and multivitamins, the physical activities, moods, sleep times of the students with the pandemic were influential on the students' use of vitamin $\mathrm{C}$ before and after the pandemic (Table 3; $\mathrm{p}<0.05$ ). According to correlations, it can be said that the higher grades used less vitamin $\mathrm{C}$, and students may take multivitamins with vitamin $\mathrm{C}$. Besides, there was a significant negative relationship between vitamin $C$ usage and sleep time change during the pandemic (149). Maybe, for this reason, it can be said that there is a significant difference in the intake of vitamin $C$ supplements due to reasons such as the fact that the dietetic students participating in our research have more fear at the beginning of the pandemic in protection from Covid-19, and the sudden change in their emotional status and daily life by leaving the university social life.

The correlations between demographics and all other parameters (such as eating habits, food additive usage, physical activity, emotional change, etc.) before and during the pandemic were given in Table $4(\mathrm{p}<0.05)$. It could be mentioned that demographics and other parameters are generally negatively correlated. Serin and Koç [12] stated that they found a significant difference in all variables such as age, gender, self-isolation, and regular physical activity at home during Covid-19 and before, in their study, they examined the eating behaviors and depression status of 1064 university students who stayed at home during the coronavirus pandemic. On the other hand, another Covid-19 study conducted on individuals living in Italy found that age was effective on people's food consumption habits, while other sociodemographic characteristics (gender, educational status, etc.) were not [9].

According to our results, since they took more classes related to nutrition, higher grade students used more vitamin $\mathrm{C}$, collagen, selenium supplements before the pandemic decreased $(p<0.05)$ (Table 4). Similarly, as the age of the students increased (older stu- 
dents), they consumed fewer snacks (chips, chocolate, etc.) ( $\mathrm{p}<$ 0.05). However, since the higher-grade students are older and their graduation dates are closer, their career plans have been adversely affected by the pandemic, and the anxiety of finding a job has increased $(\mathrm{p}<0.05)$ (Table 4$)$. Therefore, especially for last year students, alternative plans such as training and projects are to be developed in order to fulfill their graduation or social support, and encouraging them by university counseling centers (financial support, job finding, etc.) can be done [39,47].

The current study indicated that male students had higher body weight with positively correlated food supplements for physical performance and consumption of dairy products ( $p<0.05)$. It is thought that female students are generally more active during the day than male students since they do more cooking and housework during quarantine at home. It is predicted that inactivity causes weight gain in male students. Interestingly, higher height students had lower feelings of anxiety and fear, but higher selenium supplements were used $(\mathrm{p}<0.05)$. It has been determined that selenium plays a vital role in controlling the oxidative stress of viral pathogens in the host; therefore, selenium deficiency causes the weakening of the defense against infectious diseases. For this reason, a recent study conducted in China stated that low selenium intake increased mortality caused by COVID-19 [48].

During the pandemic, a positive correlation was observed between the increase in weight gain of the students and the consumption of cereal-type foods and emotional changes (Table 4). The students have been affected adversely and consumed more fat and carbohydrate food since they stayed at home, experienced social isolation, doing only necessary/necessary shopping, and decreased mobility at home. For this reason, while the students are protected from the Covid-19 pandemic, it poses a risk in terms of increasing non-communicable chronic diseases, especially obesity. A study conducted on adult individuals in Istanbul determined that almost one-third of the participants consumed more sugary foods to relieve themselves psychologically. Similar to our results, cereal meal consumption contributed to the individuals' weight increase throughout the epidemic [49]. Our results suggest that the desire to overeat due to the stress caused by staying at home should be overcome not with food but with various occupations, such as reading a book, doing exercise at home.

Besides, due to the COVID-19 outbreak, schools in Turkey and other countries have been indefinitely locked down at all levels. Although universities have developed online portals to deliver lectures, the uncertainty of academic development would have an adverse impact on students' psychological health. Most of the students are unable to attend online classes because of some technical problems. Online learning and working from home was complex. Besides, it was found that most of the students had Covid-19 symptoms as well, which may lead to psychological distress [14,19,50]. The result of our study showed that generally, depression emotions were positively correlated with eating habits more than the demographic properties ( $\mathrm{p}<0.05$ ) (Table 5$)$. It has been determined that the students' stress level has increased, affecting the students' dietary habits. However, the happiness scores of the students during the pandemic were positively related to the food supplement and probiotics intake before the pandemic $(\mathrm{p}<0.05)$. The negative impact of the pandemic on mental health may be continuous and long-term [51]. Therefore, strategies to battle the undesirable consequences of the Covid-19 pandemic on students should be proposed, such as providing adequate information about online face-to-face lectures, improving communication and psychological assistance, and so on [40].

\section{Strengths and limitations}

We collected detailed information about nutritional habits and food supplement intake before and during the three months of the pandemic in a large sample of Turkish dietetic students. Our study was timely as the data were collected almost three months after the pandemic occurred in Turkey. In other respects, due to this exceptional situation, we compared food consumption in the summer time June-July 2020. We could have expected a season effect in our data, with an improvement of the nutritional quality of diet in the summertime compared to spring due to increased availability of fresh fruit and vegetables. However, a sample size of 211 participants are still allowed to detect minor effects of students. A limitation of this study is that the sample was not representative of the Turkish student population and included more students with higher educational levels as masters and Ph.D. degrees. Furthermore, height and weight could not be measured and taken with the student statement.

\section{Conclusion}

In this research, the results showed the Covid-19 pandemic had a significant change in the routine lives of the dietetic students, on 
their emotional moods, physical activities, and daily sleep time. However, generally, there was no change in the number of meals they ate before or during to pandemic. Interestingly, the foods most frequently consumed by the students during the pandemic were vegetables and fruits. Food supplements such as vitamin D, multivitamins, and probiotics intake did not change but increased vitamin C usage significantly via the Covid-19 pandemic $(p<0,05)$. Vitamin $\mathrm{C}$ supplements intake is positively related to the student's grade, physical activity change, vitamin $\mathrm{D}$ and probiotic intake, and sadness but negatively related to sleep time change. Negative emotional moods such as fear, anxiety, sadness, and boredom were increased, respectively, during the pandemic. Interestingly, the eating habits of students were more effective than their demographic properties on their depression. This emphasizes the critical role of universities in shaping behaviors related to food choice. Collectively, these findings suggest that more research is needed to understand the long-term impacts of Covid-19 on nutritional habits of supplementary food usage. The findings of our study highlight the importance of educating the students about nutrition on COVID-19 can play a vital role in their protection from getting infected with the disease and dramatically reduce the adverse effects of the disease. Therefore, it is important to take classes related to human nutrition for students outside of nutrition and health. It is also crucial to generate a nutrition literacy culture in adults. It has been suggested to the dietitians to give information on maintaining public health and avoiding diseases. Moreover, more importantly, recommended three preventive strategies to on Covid-19 pandemic (mask, distance, and hygiene) should be promoted quality sleep, balanced eating habits, and physical activity to maintain healthy lifestyle behaviors in the long term.

\section{Acknowledgments}

The authors thank the students who participated in this research.

\section{Conflicts of Interest}

The authors declare that they have no conflicts of interest.

\section{Data Availability Statement}

The datasets generated and/or analyzed during the current study are not publicly available in order to protect participant anonymity and confidentiality.

\section{Bibliography}

1. Gralinski LE and Manechery VD. "Return of the Coronavirus: 2019-nCoV”. Viruses 12 (2020): 135.

2. Word Health Organization WHO (2021). WHO Coronavirus (COVID-19) Dashboard.
3. Kutlu R. "What We Have Learned About the New Coronavirus Pandemic, Current Diagnostic and Therapeutic Approaches and The Situation in Turkey". Turkish Journal of Family Medicine and Primary Care 14.2 (2020): 329-344.

4. Turkey Health Ministry (2021). Turkey Ministry of Health Covid-19 Information Platform.

5. Dilber A and Dilber F. "The Effect of Coronavirus (COVID-19) Disease on the Nutritional Habits of Individuals: The Case of Karaman Province". Journal of Tourism and Gastronomy Studies 8.3 (2020): 2144-2162.

6. Di Renzo L., et al. "Eating habits and lifestyle changes during COVID-19 lockdown: an Italian survey". Journal of Translational Medicine 18 (2020): 229.

7. Anonymous (2021). Nutrition Recommendations of the Turkish Dietetic Associaton on Coronavirus (Covid-19).

8. Kuru Yasar R and Üstün Aytekin Ö. "Current Overview of Relationship between COVID-19 and Nutrition". Akademik Gıda 19.1 (2021): 108-115.

9. Savarese M., et al. "COVID-19 disease and nutritional choices: How will the pandemic reconfigure our food psychology and habits? A case study of the Italian population". Nutrition, Metabolism and Cardiovascular Diseases 31 (2021): 399e402.

10. Akyol P and Çelik A. "Invesilgation of Nutrition Habits of First and Emergency Aid Students During the Covid-19 Outbreak Period". Turkish Studies 15.4 (2020): 25-37.

11. Ünal E., et al. "Impact of the Covid-19 Pandemic on Feeding and Hygiene Habits of Nursing Students". Uludağ Üniversitesi Tıp Fakültesi Dergisi 46.3 (2020): 305-311.

12. Serin E and Koç MC. "Examination of the eating behaviours and depression states of the university students who stay at home during the coronavirus pandemic in terms of different variables". Progress in Nutrition 22.1 (2020): 33-43.

13. Marty L., et al. "Food choice motives and the nutritional quality of diet during the COVID-19 lockdown in France". Appetite 157 (2021): 105005.

14. Chi X., et al. "Mental health problems among Chinese adolescents during the COVID-19: The importance of nutrition and physical activity". International Journal of Clinical and Health Psychology 21.3 (2021): 100218.

15. Çeri NG and Sakallı G. "An Overview of the Studies about Covid-19 Published on Dergipark in Our Country". 4th Agriculture, Environment and Health Congress, Aydın Adnan Menderes University, Turkey (2021). 
16. Kutluay Merdol T. "Past, Present and Future of Nutrition and Dietetics Science”. İzmir Kâtip Çelebi Üniversitesi Sağlık Bilimleri Fakültesi Dergisi 1.1 (2016): 1-5.

17. Özenoğlu A., et al. "The Effect of Health Education on Nutritional Status and Healthy Lifestyle Behavior Among University Students". ACU Sağllk Bilimleri Dergisi 9.3 (2018): 234-242.

18. Ahmed MZ., et al. "Epidemic of COVID-19 in China and associated Psychological Problems". The Asian Journal of Psychiatry 51 (2020): 102092.

19. Williams B., et al. "Impact of COVID-19 on paramedicine students: A mixed methods study". International Emergency Nursing 56 (2021): 100996.

20. Błaszczyk-Bebenek E., et al. "Nutrition Behaviours in Polish Adults before and during COVID-19 Lockdown". Nutrients 12 (2020): 3084.

21. Korkut Gençalp D. "Evaluation of Dietary Habits and Physical Activity Status of First and Emergency Aid Students in COVID-19 Outbreak Period". Journal of Paramedic and Emergency Health Services, JOPEHS 1.1 (2020): 1-15.

22. Macit MS. "Evaluation of Changes in the Nutritional Habits of Adults After Covid-19 Outbreak". Mersin Univ Saglık Bilim Derg 13.3 (2020): 277-288.

23. Bayrak U., et al. "The Knowledge and Attitude of Unıversity Students About Health Habitude and Cancer". DEÜ Tip Fakültesi Dergisi 24.3 (2010): 95-104

24. Arslan M. "Analysis of Eating Habits and Physical Activity Levels: A Study on Marmara University Faculty Academicians". Dicle Medical Journal 45.1 (2018): 59-69.

25. Bora Ö. "Gıda Takviyesi Kullanım Araștırması” (2017). PSOS Sosyal Arastırması Enstitusu.

26. Hilal Batmaz. "Yetişkinler İçin Beslenme Bilgi Düzeyi Ölçeği Geliştirilmesi ve Geçerlik-Güvenirlik Çalışması". Yüksek Lisans Tezi Marmara Üniversitesi (2020).

27. Schoeller DA. "The effect of holiday weight gain on body weight". Physiology and Behaviour 134 (2014): 66-69.

28. Chen P., et al. "Coronavirus disease (COVID-19): The need to maintain regular physical activity while taking precautions". Journal of Sport and Health Science 9 (2020): 103104.

29. Zhu W. "Should, and How can, Exercise be Done During a Coronavirus Outbreak? An interview with Dr. Jeffrey A. Woods". Journal of Sport and Health Science 9 (2020): 105107.
30. World Health Organization (WHO) Physical activity (2020).

31. FAO (The Food and Agriculture Organization). Food and maintaining a healthy diet during the COVID-19 pandemic (2020).

32. Aydoğdu GS and Köksal E. "Üniversite Öğrencilerinin Covid-19 Pandemi Sürecinde Yaşam Tarzı Değişikliklerinin Değerlendirilmesi". 4th Agriculture, Environment and Health Congress. Aydın Adnan Menderes University (2021).

33. Garipoğlu G and Bozar N. "Changes to the Nutritional Habit of the Individuals in Social Isolation in the Covid-19 Pandemic". Pearson Journal of Social Sciences and Humanities 6.6 (2020): 100-113.

34. Boretti A and Banik BK. "In travenous Vitamin C for Reduction of Cytokines Storm in Acute Respiratory Distress Syndrome". Pharma Nutrition 12 (2020): 100190.

35. Carr AC. "A New Clinical Trial to Test High-dose Vitamin C in Patients With COVID-19". Critical Care 24.1 (2020): 133.

36. Cheng R Z. "Can Early and High Intravenous Dose of Vitamin C Prevent and Treat Coronavirus Disease 2019 (COVID-19)?" Medicine in Drug Discovery 5 (2020): 100028.

37. Wang L., et al. "Review of the 2019 novel coronavirus (SARSCoV-2) based on current Evidence". International Journal of Antimicrobial Agents 55 (2020): 105948.

38. Ilie P C., et al. "The role of vitamin D in the Prevention of Coronavirus Disease 2019 Infection and Mortality". Aging Clinical and Experimental Research 32.7 (2020): 1-4.

39. Aslan İ. "Evaluating Wellbeing and Worries of University Students during Covid-19 Pandemic". Atatürk Üniversitesi İktisadi ve İdari Bilimler Dergisi 35.1 (2021): 245-261.

40. Camacho-Zu niga C., et al. "The impact of the COVID-19 pandemic on students' feelings at high school, undergraduate, and postgraduate levels". Heliyon 7 (2021): e06465.

41. Al-Domi H., et al. "Healthy nutritional behavior during COVID-19 lockdown: A crosssectional study". Clinical Nutrition ESPEN 42 (2021): 132e137.

42. Mota Santana J., et al. "Dietary intake of university students during COVID-19 social distancing in the Northeast of Brazil and associated factors". Appetite 162 (2021): 105172.

43. Ruiz-Roso MB., et al. "Covid-19 confinement and changes of adolescent's dietary trends in Italy, Spain, Chile, Colombia and Brazil”. Nutrients 12.6 (2020): 1807. 
44. Jafari D., et al. "Vitamin C and the Immune System". In Nutrition and Immunity. Edited by M.Mahmoudi, N. Rezaei, Springer, Switzerland (2019): 81-102.

45. Carr A C. "A new clinical trial to test high-dose vitamin $\mathrm{C}$ in patients with COVID-19". Critical Care 24.1 (2020): 133.

46. Cheng RZ. "Can early and high intravenous dose of vitamin C prevent and treat coronavirus disease 2019 (COVID-19)?" Medicine in Drug Discovery 5 (2020): 100028.

47. Liu M., et al. "Fruit and vegetable intake in relation to depressive andanxiety symptoms among adolescents in 25 low- and middle-income countries". Journal of Affective Disorders 261 (2020): 172-180.

48. Kuru Yaşar R and Üstün Aytekin Ö. "Current Overview of Relationship between COVID-19 and Nutrition". Akademik Gıda 19.1 (2021): 108-115.

49. Garipoğlu G and Bozar N. "Changes to the nutrıtıonal habit of the individuals in social isolation in the covid-19 pandemic". Pearson Journal of Social Sciences and Humanities 6.6 (2020): 100-113.

50. Dhahri AA., et al. Medical Education Pakistan (MEP) collaborator group, Amer Mian M. "The psychological impact of COVID-19 on medical education of final year students in Pakistan: A cross-sectional study". Annals of Medicine and Surgery 60 (2020): 445-450.

51. Shafiq S., et al. "Exploring the triggering factors for mental stress of university students amid COVID-19 in Bangladesh: A perception-based study". Children and Youth Services Review 120.1 (2021): 105789.

Volume 5 Issue 12 December 2021

(C) All rights are reserved by Ayse Demet Karaman., et al. 